\title{
What is the impact of Covid-19 on the Antenatal Care Services Utilization in Public-Private-Rural-Urban Hospitals of India during the COVID-19 Pandemic Period of 2020-2021 compared to pre-pandemic era 2018-2019?
}

Dr Piyush Kumar ( $\nabla$ drpiyush003@gmail.com)

Health Department, Government of Bihar, India https://orcid.org/0000-0001-9857-478X

\section{Research Article}

Keywords: antenatal care, health facility, utilization, coronavirus disease, pregnant women, India

Posted Date: January 25th, 2022

DOl: https://doi.org/10.21203/rs.3.rs-1286087/v1

License: @ (i) This work is licensed under a Creative Commons Attribution 4.0 International License. Read Full License

Version of Record: A version of this preprint was published at MODERN APPLIED MEDICAL RESEARCH on February 14th, 2022. See the published version at https://doi.org/10.36099/mamr.220522. 


\section{Abstract \\ Background}

The ongoing coronavirus (COVID-19) pandemic is well documented to have a disastrous effect on the health-care services, particularly pregnancy-related health services. In order to provide the information to the scientific community and policy makers with accredited evidence and data in the country, this retrospective cross sectional mixed research study aims to find out the impact of the COVID-19 pandemic on antenatal services utilization among pregnant women of India attending public / private / rural / urban health facilities in 36 states and union territories. Hence, the researcher hopes that result and analysis will be beneficial to important stakeholders as well as policy makers in designing strategies for prioritizing pregnancy healthcare even within the ongoing COVID-19 pandemic period.

\section{Methods}

A facility-based retrospective mixed cross-sectional study was conducted from 1st January 2018 to 31st May 2021 for pregnant women attending public / private / rural / urban ANC services in 36 states and union territories of India. A total of 96990524 women registered for ANC during this period across all health facilities were included in the study with a purposive sampling technique. The data required for this study is collected from HMIS of Ministry of Health and Family Welfare (MoHFW) which is the most accredited data source in India. The total number of indicators included for the study was 20 .The data collected is analysed with the help of Microsoft office.

\section{Results}

Overall, 96990524 women registered for ANC during the study period. The analysis shows that the covid-19 pandemic era has a negative impact on several indicators. The study revealed that there is significant increase in ANC service utilization at urban health facility of all the services as compared to pre-pandemic era on cumulative all India basis.

\section{Conclusion}

Enhancing women knowledge of protective health services, prioritizing maternal care related health services during ongoing COVID-19, and improving the accessibility of ANC service should be emphasized for getting maximum benefit to the neediest.

\section{Introduction}

Antenatal care services are well documented by several researchers to be affected by the COVID-19 pandemic despite the truth that pregnant women are considered vulnerable group [1]. However, the SARS-CoV-2 pandemic has led to maternity services disruptions in providing antenatal care due to the government enforced covid-19 restrictions regarding social distancing etc., which has negatively impacted on access to routine antenatal care.

The SARS-CoV-2, which causes disease (COVID-19), has spread globally since emerging in December 2019, and the World Health Organization (WHO) declared this a global pandemic on March 11, 2020[2]. Total number of 343,516,850 confirmed cases and $\mathbf{5 , 5 9 4 , 9 9 4}$ deaths $\mathbf{2 7 5 , 1 1 6 , 4 5 2}$ recovered were reported globally as of January $21,2022,10: 43$ GMT [3].

The WHO defines Antenatal care as the care given to a pregnant mother before birth, and it involves education, screening, counselling added with treatment of problems, and immunization [4].Antenatal care is the first contact opportunity for a pregnant woman to get connected with available-accessible-affordable health services and linking herself with pregnancy related complications to an established health-referral system. 
Maternal mortality is significantly high. Almost 295000 women died during and following due to pregnancy and childbirth related causes in 2017. The great majority of these deaths (94\%) reported in low-resource settings, and majority could have been prevented [5]. Antenatal healthcare is targeted to reduce maternal morbidity and mortality by providing and educating about health promotion, danger signs, birth preparedness, and proper timely care for pregnancy complications. The WHO recommends a minimum of 04 ANC visit per pregnancy for pregnant women. NFHS Studies conducted in different states of India reported that educational status, maternal age, number of living children, occupation, place of residence, religion, socioeconomic status, and previous obstetric history were significant factors associated with the use of antenatal care service [6].

The COVID-19 pandemic challenged not only India but global countries to provide good quality, essential maternal and newborn health services [7]. Pregnant women and newborns have experienced difficulties accessing health services due to lockdown measures or found to be reluctant to visit health facilities due to fear of possible infection[8]. The disruption of maternity services and moving resources away from most essential pregnancy care, due to COVID-19 response, increased risks of maternal morbidity and mortality [9]. Anxiety, domestic violence and mental health problems in pregnant women were reported to be increased during the ongoing covid-19 pandemic $[10,11]$.The indirect effects of COVID-19 on various other diseases at the population level, as a result of lockdown, social restrictions, and reorganization of health systems, is evident in several research studies[12]

The negative impact of containment and covid-19 policies on mortality at emergency department is also evident from several research studies [13]. To the best of the researcher/author knowledge, there is no published research till today 22-01-2022 exploring the effect of the COVID-19 pandemic on antenatal care services utilization by analysing 20 accredited times bound indicators for pregnant women in the country. This kind of research study is not done only in India, but also on global basis the author has not found such study which can clearly mark the impact of covid-19 on ANC through several process or output indicators.

In order to provide the information to the scientific community and policy makers with accredited evidence and data in the country, this retrospective cross sectional mixed research study aims to find out the impact of the COVID-19 pandemic on antenatal services utilization among pregnant women of India attending public / private / rural / urban health facilities in 36 states and union territories. Hence, the researcher hopes that result and analysis will be beneficial to important stakeholders as well as policy makers in designing strategies for prioritizing pregnancy healthcare even within the ongoing COVID-19 pandemic period.

\section{Materials And Methods}

Study Setting

The study was conducted by continuous observation of health facilities data found in HMIS of MoHFW, which is also available online. The population covered is 36 states and union territories of India. According to the data obtained from HMIS, the total ANC registered during this period is 96990524 numbers of females. In the country there are private, public, rural and urban hospitals, delivering ANC services. The financial burden of ANC services in public hospital of India is cost free, covered by state and central governments. For getting treatment at private health facilities the pregnant women or family have to pay as oope (out of pocket expense) until unless covered by some government sponsored scheme.

Study Design and Period

A health facility-based retrospective mixed cross-sectional study was conducted for pregnant women who attended ANC and takes the available services in the selected health facilities from 1st January 2018 to 31st May 2021. The first documented covid-19 case in India was found in January 2020[14]. Hence the year before 2020 i.e. 2018 and 2019 is pre-pandemic period utilized for comparison with the ongoing covid-19 pandemic period i.e.2020 and 2021 (up to May as data from accredited source is available till this month). The average per month is calculated and pandemic era is compared with pre-pandemic era to find out the impact of covid-19 on ANC services utilization.

Page $3 / 29$ 
Population

The actual population was all the pregnant women who attended ANC or utilized ANC related health services in the selected health facilities of choice, during the data collection period of this research study was considered as study population.

Accordingly, a total of 96990524 numbers of female's pregnant women who fulfilled the inclusion criteria were included in the study.

Sample Size and Sampling Technique

A total of 96990524 women registered for ANC were included in the study with a purposive sampling technique. The data required for this study is collected from HMIS of Ministry of Health and Family Welfare (MoHFW) which is the most accredited data source in India. The total number of indicators included for the study was 25 . The data collected is analysed with the help of Microsoft office.

Study Variables and Operational Definition

The outcome variable of this research study was antenatal care utilization. Antenatal care utilization for this study was defined as

1. Total number of pregnant women registered for ANC

2. Out of the total ANC registered, number registered within 1st trimester (within 12 weeks)

3. Number of PW given TT1/ Td1

4. Number of PW given TT2 / Td2

5. Number of PW given TT Booster/ Td Booster

6. Number of PW provided full Course 180 Iron Folic Acid (IFA) tablets

7. Number of PW provided full Course 360 Calcium tablets

8. Number of PW given one Albendazole tablet after 1st trimester

9. Number of PW received 4 or more ANC check ups

10. Number of PW given ANC Corticosteroids in Pre Term Labour

11. Out of the new cases of PW with hypertension detected, cases managed at institution

12. Number of Eclampsia cases managed during delivery

13. Number of PW tested for Haemoglobin $(\mathrm{Hb}) 4$ or more than 4 times for respective ANCs

14. Number of PW having severe anaemia $(\mathrm{Hb}<7)$ treated

15. Number of PW tested for Blood Sugar using OGTT(Oral Glucose Tolerance Test)

16. Number of PW tested positive for GDM

17. Number of PW given insulin out of total tested positive for GDM

18. Number of PW tested using POC test for Syphilis

19. Number of pregnant women tested for Syphilis

20. Number of syphilis positive pregnant women treated for Syphilis,

Data Collection and Quality Assurance

Data were continuously collected, observed analysed using Microsoft office software from electronic records of HMIS from MoHFW. The whole data collection and analysis is solely done by the author. To assure data quality the researcher has taken help of his wife to do cross check as well. Furthermore, there was daily supervision of data collected in the data collection process. Finally, it was checked for accuracy, reliability, completeness and consistency.

Data Management and Analysis

All data was checked for inconsistencies, any missing values, and for incompleteness, then entered into Microsoft office software and also exported to STATA for further analysis.

Page $4 / 29$ 
The data for study is available on HMIS of Ministry of Health and Family Welfare, Government of India. The link to the source is given below:-

https://hmis.nhp.gov.in/\#!/standardReports

\section{Ethical Consideration}

Ethical clearance was not applicable as this research study have not utilized any human or animal for trials etc. or involved them in any way which requires ethical considerations. Furthermore the data used is available for public and the researcher have not disclosed any hidden or secret data. The purpose of this study is well explained above, and consent or approval is not required for such studies based on secondary data available in public domain. The researcher is a medical doctor and this research study is a part of author usual routine.

\section{Results}

Socio-Demographic Characteristics of Respondents

A facility-based retrospective mixed cross-sectional study was conducted from 1st January 2018 to 31st May 2021 for pregnant women attending all / public / private / rural / urban ANC services in 36 states and union territories of India. Thus, a total of 96990524 women registered for ANC were included in the study with a purposive sampling technique. See Table 1, 2, $3,4,5$,(some extra data table is also attached at end for researchers interest)

This research study is ongoing and more analysis and interpretation will be available in next version of this research study with more data.

Impact of COVID-19 Pandemic on ANC Service Utilization

Table - 1- Comparison of ANC service utilization across India (all health facilities) before and after covid-19 pandemic 


\begin{tabular}{|c|c|c|}
\hline Indicator/ Variable & $\begin{array}{l}\text { Average per month-Pandemic } \\
\text { Era (2020-21) }\end{array}$ & $\begin{array}{l}\text { Average per month-Pre- } \\
\text { Pandemic Era } \\
(2018-2019)\end{array}$ \\
\hline Total number of pregnant women registered for ANC & 2309294.7 & 2414769 \\
\hline $\begin{array}{l}\text { Out of the total ANC registered, number registered within 1st } \\
\text { trimester (within } 12 \text { weeks) }\end{array}$ & 1725702.3 & 1662208 \\
\hline Number of PW given TT1/ Td1 & 1650691.2 & 1734836 \\
\hline Number of PW given TT2 / Td2 & 1459628.4 & 1555820.5 \\
\hline Number of PW given TT Booster/ Td Booster & 514934.24 & 497145.75 \\
\hline $\begin{array}{l}\text { Number of PW provided full Course } 180 \text { Iron Folic Acid (IFA) } \\
\text { tablets }\end{array}$ & 2080879.9 & 2072583.5 \\
\hline Number of PW provided full Course 360 Calcium tablets & 1853213.6 & 1474173.5 \\
\hline $\begin{array}{l}\text { Number of PW given one Albendazole tablet after 1st } \\
\text { trimester }\end{array}$ & 1143783 & 945783.85 \\
\hline Number of PW received 4 or more ANC check ups & 1801079 & 1802186.5 \\
\hline $\begin{array}{l}\text { Number of PW given ANC Corticosteroids in Pre Term } \\
\text { Labour }\end{array}$ & 38021.317 & 35867.25 \\
\hline New cases of PW with hypertension detected & 46943.875 & 48617.71 \\
\hline $\begin{array}{l}\text { Out of the new cases of PW with hypertension detected, } \\
\text { cases managed at institution }\end{array}$ & 33567.525 & 32482.96 \\
\hline Number of Eclampsia cases managed during delivery & 5051.6167 & 5005.875 \\
\hline $\begin{array}{l}\text { Number of PW tested for Haemoglobin ( } \mathrm{Hb}) 4 \text { or more than } \\
4 \text { times for respective ANCs }\end{array}$ & 1803885.8 & 1927255.5 \\
\hline $\begin{array}{l}\text { Number of PW having } \mathrm{Hb} \text { level }<11 \text { (out of total tested cases) } \\
\text { (7.1 to 10.9) }\end{array}$ & 1508156 & 1706392.5 \\
\hline Number of PW having $\mathrm{Hb}$ level<7 (out of total tested cases) & 72676.35 & 88738.625 \\
\hline Number of PW having severe anaemia $(\mathrm{Hb}<7)$ treated & 44108.592 & 49309.625 \\
\hline $\begin{array}{l}\text { Number of PW tested for Blood Sugar using OGTT(Oral } \\
\text { Glucose Tolerance Test) }\end{array}$ & 368095.89 & 343927.75 \\
\hline Number of PW tested positive for GDM & 10798.183 & 11486 \\
\hline $\begin{array}{l}\text { Number of PW given insulin out of total tested positive for } \\
\text { GDM }\end{array}$ & 2990.3917 & 2328.4165 \\
\hline Number of PW tested using POC test for Syphilis & 215142.48 & 32339.21 \\
\hline Out of above, number of PW found sero-positive for Syphilis & 1499.9917 & 379.2083 \\
\hline Number of pregnant women tested for Syphilis & 694791.53 & 732651.45 \\
\hline $\begin{array}{l}\text { Number of pregnant women tested found sero positive for } \\
\text { Syphilis }\end{array}$ & 3670.8917 & 3673.542 \\
\hline $\begin{array}{l}\text { Number of syphilis positive pregnant women treated for } \\
\text { Syphilis }\end{array}$ & 1573.55 & 1261.375 \\
\hline
\end{tabular}

The study revealed that there is decrease in ANC service utilization of following services as compared to pre-pandemic era on cumulative all India basis:- 
- Total number of pregnant women registered for ANC-Number of PW given TT1/ Td1

- Number of PW given TT2 / Td2

- Number of PW received 4 or more ANC check ups

- Number of PW tested for Haemoglobin $(\mathrm{Hb}) 4$ or more than 4 times for respective ANCs

- Number of pregnant women tested for Syphilis

An important finding is increase in following ANC service utilization during covid-19 pandemic Era:-

- Number of PW tested using POC test for Syphilis

- Out of above, number of PW found sero-positive for Syphilis

- Number of syphilis positive pregnant women treated for Syphilis

Table - 2-Comparison of ANC service utilization at public health facilities across India before and after covid-19 pandemic 


\begin{tabular}{|c|c|c|}
\hline Indicator / & $\begin{array}{l}\text { Public Average per month- } \\
\text { Pandemic Era }\end{array}$ & $\begin{array}{l}\text { Public Average per month- } \\
\text { Pre-Pandemic Era }\end{array}$ \\
\hline Total number of pregnant women registered for ANC & 2208203 & 2314360 \\
\hline $\begin{array}{l}\text { Out of the total ANC registered, number registered within } \\
1 \text { st trimester (within } 12 \text { weeks) }\end{array}$ & 1662352.5 & 1605446.5 \\
\hline Number of PW given TT1/ Td1 & 1566090.5 & 1645625.5 \\
\hline Number of PW given TT2 / Td2 & 1392607.5 & 1481007 \\
\hline Number of PW given TT Booster/ Td Booster & 491451.45 & 476094.6 \\
\hline $\begin{array}{l}\text { Number of PW provided full Course } 180 \text { Iron Folic Acid } \\
\text { (IFA) tablets }\end{array}$ & 2002525.5 & 2009726 \\
\hline Number of PW provided full Course 360 Calcium tablets & 1782147 & 1420106.5 \\
\hline $\begin{array}{l}\text { Number of PW given one Albendazole tablet after } 1 \mathrm{st} \\
\text { trimester }\end{array}$ & 1112063.5 & 927973.95 \\
\hline Number of PW received 4 or more ANC check ups & 1730049.5 & 1739785.5 \\
\hline $\begin{array}{l}\text { Number of PW given ANC Corticosteroids in Pre Term } \\
\text { Labour }\end{array}$ & 34949.625 & 32516.54 \\
\hline New cases of PW with hypertension detected & 42436.215 & 43997.665 \\
\hline $\begin{array}{l}\text { Out of the new cases of PW with hypertension detected, } \\
\text { cases managed at institution }\end{array}$ & 30312.55 & 29495.5 \\
\hline Number of Eclampsia cases managed during delivery & 4629.0585 & 4606 \\
\hline $\begin{array}{l}\text { Number of PW tested for Haemoglobin }(\mathrm{Hb}) 4 \text { or more than } \\
4 \text { times for respective ANCs }\end{array}$ & 1738688.5 & 1874225 \\
\hline $\begin{array}{l}\text { Number of PW having } \mathrm{Hb} \text { level }<11 \text { (out of total tested } \\
\text { cases)( } 7.1 \text { to 10.9) }\end{array}$ & 1469851 & 1667481 \\
\hline Number of PW having $\mathrm{Hb}$ level $<7$ (out of total tested cases) & 68486.65 & 83875.165 \\
\hline Number of PW having severe anaemia $(\mathrm{Hb}<7)$ treated & 40909.89 & 46005.125 \\
\hline $\begin{array}{l}\text { Number of PW tested for Blood Sugar using OGTT(Oral } \\
\text { Glucose Tolerance Test) }\end{array}$ & 336444.35 & 320643.6 \\
\hline Number of PW tested positive for GDM & 8575.35 & 9711.25 \\
\hline $\begin{array}{l}\text { Number of PW given insulin out of total tested positive for } \\
\text { GDM }\end{array}$ & 2204.1915 & 1654.708 \\
\hline Number of PW tested using POC test for Syphilis & 215122.4 & 32318.875 \\
\hline $\begin{array}{l}\text { Out of above, number of PW found sero positive for } \\
\text { Syphilis }\end{array}$ & 1499.99165 & 379.2083 \\
\hline Number of pregnant women tested for Syphilis & 648700.65 & 702290.65 \\
\hline $\begin{array}{l}\text { Number of pregnant women tested found sero positive for } \\
\text { Syphilis }\end{array}$ & 3460.9585 & 3535.7085 \\
\hline $\begin{array}{l}\text { Number of syphilis positive pregnant women treated for } \\
\text { Syphilis }\end{array}$ & 1436.3665 & 1217.208 \\
\hline
\end{tabular}

The study revealed that there is decrease in ANC service utilization at public health facility of following services as compared to pre-pandemic era on cumulative all India basis:- 
- Total number of pregnant women registered for ANC

- Number of PW given TT1/ Td1

- Number of PW given TT2 / Td2

- Number of PW provided full Course 180 Iron Folic Acid (IFA) tablets

- Number of PW received 4 or more ANC check ups

- Number of PW tested for Haemoglobin $(\mathrm{Hb}) 4$ or more than 4 times for respective ANCs

- Number of PW having severe anaemia $(\mathrm{Hb}<7)$ treated

- Number of pregnant women tested for Syphilis

An important finding is increase in following ANC service utilization at public health facility during covid-19 pandemic Era:-

- Number of PW tested using POC test for Syphilis

- Out of above, number of PW found sero-positive for Syphilis

- Number of syphilis positive pregnant women treated for Syphilis

Table - 3- Comparison of ANC service utilization at private health facilities across India before and after covid-19 pandemic 


\begin{tabular}{|c|c|c|}
\hline Indicator / & $\begin{array}{l}\text { Private Average per month- } \\
\text { Pandemic Era }\end{array}$ & $\begin{array}{l}\text { Private Average per month- } \\
\text { Pre-Pandemic Era }\end{array}$ \\
\hline Total number of pregnant women registered for ANC & 101091.14 & 100409.19 \\
\hline $\begin{array}{l}\text { Out of the total ANC registered, number registered within } \\
1 \text { st trimester (within } 12 \text { weeks) }\end{array}$ & 63350.035 & 56761.17 \\
\hline Number of PW given TT1/ Td1 & 84600.925 & 89210.625 \\
\hline Number of PW given TT2 / Td2 & 67020.885 & 74813.5 \\
\hline Number of PW given TT Booster/ Td Booster & 23482.815 & 21051.165 \\
\hline $\begin{array}{l}\text { Number of PW provided full Course } 180 \text { Iron Folic Acid } \\
\text { (IFA) tablets }\end{array}$ & 78354.375 & 62857.625 \\
\hline Number of PW provided full Course 360 Calcium tablets & 71066.59 & 54066.875 \\
\hline $\begin{array}{l}\text { Number of PW given one Albendazole tablet after 1st } \\
\text { trimester }\end{array}$ & 31719.815 & 17809.585 \\
\hline Number of PW received 4 or more ANC check ups & 71029.54 & 62401.585 \\
\hline $\begin{array}{l}\text { Number of PW given ANC Corticosteroids in Pre Term } \\
\text { Labour }\end{array}$ & 3071.6915 & 3350.7085 \\
\hline New cases of PW with hypertension detected & 4507.6585 & 4620.042 \\
\hline $\begin{array}{l}\text { Out of the new cases of PW with hypertension detected, } \\
\text { cases managed at institution }\end{array}$ & 3254.975 & 2987.4585 \\
\hline Number of Eclampsia cases managed during delivery & 422.55835 & 399.875 \\
\hline $\begin{array}{l}\text { Number of PW tested for Haemoglobin }(\mathrm{Hb}) 4 \text { or more than } \\
4 \text { times for respective ANCs }\end{array}$ & 65197.565 & 53030 \\
\hline $\begin{array}{l}\text { Number of PW having Hb level }<11 \text { (out of total tested } \\
\text { cases)( } 7.1 \text { to } 10.9 \text { ) }\end{array}$ & 38304.95 & 38911.625 \\
\hline $\begin{array}{l}\text { Number of PW having } \mathrm{Hb} \text { level }<7 \text { (out of total tested } \\
\text { cases) }\end{array}$ & 4189.7 & 4863.4585 \\
\hline Number of PW having severe anaemia $(\mathrm{Hb}<7)$ treated & 3198.7 & 3304.5 \\
\hline $\begin{array}{l}\text { Number of PW tested for Blood Sugar using OGTT (Oral } \\
\text { Glucose Tolerance Test) }\end{array}$ & 31651.565 & 23284.125 \\
\hline Number of PW tested positive for GDM & 2222.8335 & 1774.75 \\
\hline $\begin{array}{l}\text { Number of PW given insulin out of total tested positive for } \\
\text { GDM }\end{array}$ & 786.2 & 673.70835 \\
\hline Number of PW tested using POC test for Syphilis & 20.1 & 20.33333 \\
\hline $\begin{array}{l}\text { Out of above, number of PW found sero positive for } \\
\text { Syphilis }\end{array}$ & 0 & 0 \\
\hline Number of pregnant women tested for Syphilis & 46090.865 & 30360.79 \\
\hline $\begin{array}{l}\text { Number of pregnant women tested found sero positive for } \\
\text { Syphilis }\end{array}$ & 209.93335 & 137.83335 \\
\hline $\begin{array}{l}\text { Number of syphilis positive pregnant women treated for } \\
\text { Syphilis }\end{array}$ & 137.18335 & 44.166665 \\
\hline
\end{tabular}

The study revealed that there is decrease in ANC service utilization at private health facility of following services as compared to pre-pandemic era on cumulative all India basis:- 
- Number of PW given TT1/ Td1

- Number of PW given TT2 / Td2

- Number of PW given ANC Corticosteroids in Pre Term Labour

- Number of PW having severe anaemia $(\mathrm{Hb}<7)$ treated

- Number of PW tested using POC test for Syphilis

An important finding is increase in following ANC service utilization at private health facilities during covid-19 pandemic Era:-

- Total number of pregnant women registered for ANC

- Out of the total ANC registered, number registered within 1st trimester (within 12 weeks)

- Number of PW given TT Booster/ Td Booster

- Number of PW provided full Course 180 Iron Folic Acid (IFA) tablets

- Number of PW provided full Course 360 Calcium tablets

- Number of PW given one Albendazole tablet after 1st trimester

- Number of PW received 4 or more ANC check ups

- Out of the new cases of PW with hypertension detected, cases managed at institution

- Number of Eclampsia cases managed during delivery

- Number of PW tested for Haemoglobin $(\mathrm{Hb}) 4$ or more than 4 times for respective ANCs

- Number of PW tested for Blood Sugar using OGTT (Oral Glucose Tolerance Test)

- Number of pregnant women tested for Syphilis

- Number of syphilis positive pregnant women treated for Syphilis

Table - 4- Comparison of ANC service utilization at urban health facilities across India before and after covid-19 pandemic. 


\begin{tabular}{|c|c|c|}
\hline Indicator / & $\begin{array}{l}\text { Urban Average per month- } \\
\text { Pandemic Era }\end{array}$ & $\begin{array}{l}\text { Urban Average per month- } \\
\text { Pre-Pandemic Era }\end{array}$ \\
\hline Total number of pregnant women registered for ANC & 518771.3 & 451593.7 \\
\hline $\begin{array}{l}\text { Out of the total ANC registered, number registered within } \\
1 \text { st trimester (within } 12 \text { weeks) }\end{array}$ & 343403.05 & 279530.85 \\
\hline Number of PW given TT1/ Td1 & 349543.55 & 310719.25 \\
\hline Number of PW given TT2 / Td2 & 293695.65 & 269778.9 \\
\hline Number of PW given TT Booster/ Td Booster & 102912.92 & 85386.455 \\
\hline $\begin{array}{l}\text { Number of PW provided full Course } 180 \text { Iron Folic Acid (IFA) } \\
\text { tablets }\end{array}$ & 483290.8 & 393306.2 \\
\hline Number of PW provided full Course 360 Calcium tablets & 451589.65 & 312952.3 \\
\hline $\begin{array}{l}\text { Number of PW given one Albendazole tablet after 1st } \\
\text { trimester }\end{array}$ & 227563.45 & 155192.5 \\
\hline Number of PW received 4 or more ANC check ups & 371357.45 & 297172.6 \\
\hline $\begin{array}{l}\text { Number of PW given ANC Corticosteroids in Pre Term } \\
\text { Labour }\end{array}$ & 15494.765 & 7497.875 \\
\hline New cases of PW with hypertension detected & 17067.65 & 10140.295 \\
\hline $\begin{array}{l}\text { Out of the new cases of PW with hypertension detected, } \\
\text { cases managed at institution }\end{array}$ & 12952.615 & 7149.417 \\
\hline Number of Eclampsia cases managed during delivery & 2449.4415 & 900.41685 \\
\hline $\begin{array}{l}\text { Number of PW tested for Haemoglobin }(\mathrm{Hb}) 4 \text { or more than } \\
4 \text { times for respective ANCs }\end{array}$ & 339487 & 291424.85 \\
\hline $\begin{array}{l}\text { Number of PW having Hb level }<11 \text { (out of total tested } \\
\text { cases)( } 7.1 \text { to } 10.9 \text { ) }\end{array}$ & 312497.4 & 298461 \\
\hline Number of PW having $\mathrm{Hb}$ level<7 (out of total tested cases) & 21975.99 & 15978.585 \\
\hline Number of PW having severe anaemia $(\mathrm{Hb}<7)$ treated & 16918.35 & 9425 \\
\hline $\begin{array}{l}\text { Number of PW tested for Blood Sugar using OGTT(Oral } \\
\text { Glucose Tolerance Test) }\end{array}$ & 125177.65 & 74461.67 \\
\hline Number of PW tested positive for GDM & 5035.4085 & 2772.5835 \\
\hline $\begin{array}{l}\text { Number of PW given insulin out of total tested positive for } \\
\text { GDM }\end{array}$ & 1637.3335 & 719.41665 \\
\hline Number of PW tested using POC test for Syphilis & 734.15 & 328.125 \\
\hline $\begin{array}{l}\text { Out of above, number of PW found sero positive for } \\
\text { Syphilis }\end{array}$ & 25.333335 & 12.666669 \\
\hline Number of pregnant women tested for Syphilis & 255750.1 & 153349.8 \\
\hline $\begin{array}{l}\text { Number of pregnant women tested found sero positive for } \\
\text { Syphilis }\end{array}$ & 1302.8334 & 1047.0419 \\
\hline $\begin{array}{l}\text { Number of syphilis positive pregnant women treated for } \\
\text { Syphilis }\end{array}$ & 506.975 & 244.6667 \\
\hline
\end{tabular}

- The study revealed that there is significant increase in ANC service utilization at urban health facility of all the services as compared to pre-pandemic era on cumulative all India basis. 
Table - 5- Comparison of ANC service utilization at rural health facilities across India before and after covid-19 pandemic

\begin{tabular}{|c|c|c|}
\hline Indicator / & $\begin{array}{l}\text { Rural Average per month- } \\
\text { Pandemic Era }\end{array}$ & $\begin{array}{l}\text { Rural Average per month-Pre } \\
\text { Pandemic Era }\end{array}$ \\
\hline Total number of pregnant women registered for ANC & 1790520 & 1963175.5 \\
\hline $\begin{array}{l}\text { Out of the total ANC registered, number registered within 1st } \\
\text { trimester (within } 12 \text { weeks) }\end{array}$ & 1382296 & 1382677.5 \\
\hline Number of PW given TT1/ Td1 & 1301144.5 & 1424117 \\
\hline Number of PW given TT2 / Td2 & 1165928 & 1286041.5 \\
\hline Number of PW given TT Booster/ Td Booster & 412021.3 & 411759.3 \\
\hline $\begin{array}{l}\text { Number of PW provided full Course } 180 \text { Iron Folic Acid (IFA) } \\
\text { tablets }\end{array}$ & 1597586 & 1679277.5 \\
\hline Number of PW provided full Course 360 Calcium tablets & 1401620.5 & 1161220.9 \\
\hline $\begin{array}{l}\text { Number of PW given one Albendazole tablet after } 1 \mathrm{st} \\
\text { trimester }\end{array}$ & 916217.85 & 790591.3 \\
\hline Number of PW received 4 or more ANC check ups & 1429718.5 & 1505014 \\
\hline $\begin{array}{l}\text { Number of PW given ANC Corticosteroids in Pre Term } \\
\text { Labour }\end{array}$ & 22526.55 & 28369.375 \\
\hline New cases of PW with hypertension detected & 29876.225 & 38477.415 \\
\hline $\begin{array}{l}\text { Out of the new cases of PW with hypertension detected, } \\
\text { cases managed at institution }\end{array}$ & 20614.91 & 25333.54 \\
\hline Number of Eclampsia cases managed during delivery & 2602.175 & 4105.4585 \\
\hline $\begin{array}{l}\text { Number of PW tested for Haemoglobin }(\mathrm{Hb}) 4 \text { or more than } \\
4 \text { times for respective ANCs }\end{array}$ & 1464396 & 1635830.5 \\
\hline $\begin{array}{l}\text { Number of PW having } \mathrm{Hb} \text { level }<11 \text { (out of total tested } \\
\text { cases)( } 7.1 \text { to 10.9) }\end{array}$ & 1195653 & 1407931.5 \\
\hline Number of PW having $\mathrm{Hb}$ level $<7$ (out of total tested cases) & 50700.36 & 72760.04 \\
\hline Number of PW having severe anaemia $(\mathrm{Hb}<7)$ treated & 27190.24 & 39884.625 \\
\hline $\begin{array}{l}\text { Number of PW tested for Blood Sugar using OGTT(Oral } \\
\text { Glucose Tolerance Test) }\end{array}$ & 242917.6 & 269466.1 \\
\hline Number of PW tested positive for GDM & 5762.775 & 8713.417 \\
\hline $\begin{array}{l}\text { Number of PW given insulin out of total tested positive for } \\
\text { GDM }\end{array}$ & 1353.0585 & 1609 \\
\hline Number of PW tested using POC test for Syphilis & 214408.35 & 32011.08 \\
\hline Out of above, number of PW found sero positive for Syphilis & 1474.6584 & 366.5417 \\
\hline Number of pregnant women tested for Syphilis & 439041.45 & 579301.65 \\
\hline $\begin{array}{l}\text { Number of pregnant women tested found sero positive for } \\
\text { Syphilis }\end{array}$ & 2368.0585 & 2626.5 \\
\hline $\begin{array}{l}\text { Number of syphilis positive pregnant women treated for } \\
\text { Syphilis }\end{array}$ & 1066.575 & 1016.7084 \\
\hline
\end{tabular}

The study revealed that there is decrease in almost all ANC service utilization at rural health facility except following services as compared to pre-pandemic era on cumulative all India basis: 
- Number of PW given TT Booster/ Td Booster

- Number of PW provided full Course 360 Calcium tablets

- Number of PW given one Albendazole tablet after 1st trimester

- Number of PW tested using POC test for Syphilis

- Number of syphilis positive pregnant women treated for Syphilis

\section{Discussion}

The study revealed that there is decrease in ANC service utilization of following services as compared to pre-pandemic era on cumulative all India basis:-

- Total number of pregnant women registered for ANC

- Number of PW given TT1/ Td1

- Number of PW given TT2 / Td2

- Number of PW received 4 or more ANC check ups

- Number of PW tested for Haemoglobin $(\mathrm{Hb}) 4$ or more than 4 times for respective ANCs

- Number of pregnant women tested for Syphilis

An important finding is increase in following ANC service utilization during covid-19 pandemic Era:-

- Number of PW tested using POC test for Syphilis

- Out of above, number of PW found sero-positive for Syphilis

- Number of syphilis positive pregnant women treated for Syphilis

This research study finding also revealed that urban health facility where maximum private health facilities are available was found to be associated with significantly increased utilization of antenatal care services in the pandemic era. This finding was supported by the accredited data source of HMIS - MoHFW-Gol. This might be related to the fact that pregnant women residing in urban areas may have better access as well as affordability-availability of different health facilities and better knowledge about the significance of ANC utilization.

This research study finding also revealed that rural health facility where mostly public health facilities are available was found to be associated with significantly decreased utilization of antenatal care services in the pandemic era. This finding was supported by the accredited data source of HMIS - MoHFW-Gol. This might be related to the fact that pregnant women residing in rural areas may have limited access as well as limited affordability-availability of different health facilities and lesser knowledge about the significance of ANC utilization added with lack of transport accessibility. This might be because of other reasons like fear of contracting disease stay-at-home orders leading to greater loss of income, reduced capability or (OOPE) purchasing power, resulting in inability to pay for services which in turn limit utilization of ANC services.

The situation is harsher in rural areas of developing countries like India due to the lack of proper infrastructure at public health facilities and limited resources. This might be due to public health system collapse or intentional individual choices made by public in responding to the pandemic, workforce diversion-reduction at rural-public health facilities, access reduction, and also some health facility may have restricted number of regular ANC visits due to possible fear of the pregnant women contracting coronavirus.

Strength and Limitation of the study

The cross-sectional retrospective nature of this study was one of the main limitations of this research study. Another limitation is availability of data from any other accredited and established source recognized worldwide. Furthermore, this study is not 
done with primary method of data collection. The main strength is that the whole study is based on real time based accredited government data sources which is also available $24 \times 7$ to the visitors.

\section{Conclusion And Recommendation}

This research study findings showed that the covid-19 pandemic reduced the utilization of various antenatal health care services among pregnant women in India as compared to the pre-pandemic period. Hence author recommends more efforts in rural areas as well as improvement in public health facilities for enhancing ANC health services. Various types of IEC (Information, Education and Communication) materials should be distributed to raise awareness regarding the protective ANC services for pregnant women during the COVID-19 pandemic. It is also useful to start telecommunication-consultation services to help pregnant women. In addition, virtual consultation with gynaecologist- obstetricians can be provided via teleconsultation services, to women who need maternal health services.

\section{Implications Of The Study}

COVID-19 pandemic has caused interference in delivery of health services on the global scale, including ANC. Due to this global pandemic, women who are considered a vulnerable group in time of distress particularly pregnant women are facing more barriers in availing-affording-accessing healthcare services. This is due to several reasons including covid-19 guidelinesrestrictions, transport related, anxiety, and fear of being exposed to coronavirus. This study demonstrates that improving the public and rural health facilities requirements which are not doing well in pandemic era would help to improve ANC services utilization during ongoing pandemic. Effective guidelines of preventive and clinical strategies are required to be implemented to control COVID-19 infection among pregnant women. Governments should also need to make policies during ongoing pandemic to make sure that pregnant-women can access ANC health services to protect themselves and their babies. Additionally, more arrangements should be made during pandemic to ensure transportation, accessibility, affordability and availability of ANC services during lockdown etc., to achieve SDG goal as well as health for all goals.

\section{Abbreviations}

ANC, Antenatal care; COVID-19, Coronavirus disease; WHO, World Health Organization; HMIS, Health Management Information System; MoHFW, Ministry of Health and Family Welfare; Gol, Government of India; OOPE, Out of Pocket Expense; IEC, Information, Education and Communication;

\section{Declarations}

\section{Acknowledgments}

Special thanks go to my wife Advocate Anupama and daughters Aathmika-Atheeva for their co-operation in accomplishment of this work.

\section{Disclosure}

The author reports no conflicts of interest for this research study.

\section{Declarations}

-This version of paper has not been previously published in any peer reviewed journal and is not currently under consideration by any journal. The document is Microsoft word with English (United States) language \& 4910 words (8365 words Total). The preprint of this research article is available online with DOI on various preprint servers.

- Ethics approval and consent to participate: Not applicable. This study has not involved any human or animals in real or for experiments. The data were taken from the Health Department available as electronic patient records from HMIS (health 
management information system) of MoHFW (ministry of health and family welfare), Government of India.

-Consent for publication: The authors provide consent for publication for increasing awareness and sharing knowledge to people who need it.

-Availability of data and materials: Electronic patient records from HMIS (health management information system) of MoHFW (ministry of health and family welfare), Government of India.

-Conflicts of Interest/ Competing Interest: There are no conflicts / competing of interest

- Funding-Self sponsored. No aid taken from individual or agency etc.

- Authors' contributions: The whole work is done by the Author - Dr Piyush Kumar, M.B.B.S., E.M.O.C., P.G.D.P.H.M., -Senior General Medical Officer- Bihar Health Services- Health Department- Government of Bihar, India.

- Acknowledgements- I am thankful to Advocate Anupama my wife and daughters Aathmika-Atheeva for cooperation.

- Author information: The author is currently working as Senior General Medical Officer for the government of Bihar.

-Financial Support \& sponsorship: Nil

-Author contact information

Department of Health, Government of Bihar, MOBILE - +919955301119/+917677833752, Email drpiyush003@gmail.com

\section{References}

1. Kumar, Piyush and Kumar, Piyush and Farooqui, Habib Hasan, What is the Impact of Covid-19 Pandemic on the RCH (Reproductive and Child Health) Programme in Rajasthan, Because of Nationwide Lockdown (April 2020 to June 2020)?. Available at SSRN: https://ssrn.com/abstract=3914646 or http://dx.doi.org/10.2139/ssrn.3914646

2. Kumar, Piyush and Kumar, Piyush, What Are the Factors Responsible for Increase in SARS-CoV-2/COVID-19 Pandemic Related Cases and Death in India in 2021? How Does Environmental, Host \& Agent Factors of Epidemiological Triad Do Influence \& Can Be Utilised to Manage Ongoing Pandemic Cases and Deaths? (April 25, 2021). Available at SSRN: https://ssrn.com/abstract=3833788 or http://dx.doi.org/10.2139/ssrn.3833788

3. Worldometer. Coronavirus update COVID-19 21-01-2022-16; 19 https://www.worldometers.info/coronavirus/

4. WHO recommendations on antenatal care for a positive pregnancy experience https://www.who.int/publications/i/item/9789241549912

5. Home/Newsroom/Fact sheets/Detail/Maternal mortality - WHO - https://www.who.int/news-room/factsheets/detail/maternal-mortality

6. National Family Health Survey, India - http://rchiips.org/nfhs/bihar.shtml

7. DR PIYUSH KUMAR. What Impact Have SARS-CoV-2/Covid-19 Pandemic on the Reproductive and Child Health Programme of India over the 3 months after nationwide Lock down announcement in March 2020 -A brief analysis., 25 March 2021, PREPRINT (Version 1) available at Research Square https://doi.org/10.21203/rs.3.rs-360551/v1

8. Dr. Piyush Kumar. What Impact Have SARS-CoV-2/Covid-19 Pandemic on the Reproductive and Child Health Programme of Bihar in India over the 3 months after nationwide Lock down announcement in March 2020? How SARS-CoV-2 Pandemic era does influence RCH Programme? Immunisation?\&nbsp;Maternal Health? Family Planning?, 30 March 2021, PREPRINT (Version 4) available at Research Square https://doi.org/10.21203/rs.3.rs-348841/v4 
9. What Impact Have SARS-CoV-2/Covid-19 Pandemic on the Reproductive and Child Health Programme of Uttar Pradesh in India over the 3 months after nationwide Lockdown announcement in March 2020 -A brief analysis, 29 March 2021, PREPRINT (Version 2) available at Research Square https://doi.org/10.21203/rs.3.rs-350287/v2

10. Dr Piyush Kumar, Advocate Anupama. What impact have Covid-19 pandemic era on violence against women in India - A retrospective comparative research study from January 2018 to December 2021, 14 January 2022, PREPRINT (Version 2) available at Research Square https://doi.org/10.21203/rs.3.rs-1256722/v2

11. Kumar, Piyush and Kumar, Piyush, What Impact Have SARS-CoV-2/COVID-19 Pandemic on Domestic Violence against Women in India across Different States and Union Territories from the Beginning of Lockdown Due to COVID-19 Pandemic in March 2020 Till 20Th September 2020? How COVID-19 Pandemic Induced Lockdown Influence Mental Health of Women in India? (April 15, 2021). Available at SSRN: https://ssrn.com/abstract=3826837 or http://dx.doi.org/10.2139/ssrn.3826837

12. Kumar, Piyush and Kumar, Piyush, What Impact Have SARS-CoV-2/COVID-19 Pandemic Induced Lockdown on the Number of OPD Patients of Diabetes, Hypertension, Stroke (CVA), Acute Heart Disease, Mental Illness, Epilepsy, Ophthalmic, Dental and Oncology in India During the Lockdown Months (April-May-2020)-Observational Research Analysis?. Available at SSRN: https://ssrn.com/abstract=3884940 or http://dx.doi.org/10.2139/ssrn.3884940

13. Kumar, Piyush and Kumar, Piyush, What impact Have COVID-19 Pandemic on Number of Death Occurring at the Emergency Department: A Retrospective Analysis of Mortality in India From January 2019 to May 2021. Available at SSRN: https://ssrn.com/abstract=4006146 or http://dx.doi.org/10.2139/ssrn.4006146

14. Dr Piyush Kumar,M.B.B.S., E.M.O.C., . What are the factors responsible for increase in SARS-CoV-2/Covid-19 Pandemic related cases and death in India in 2021 ? How does environmental, host \& agent factors of epidemiological triad do influence \& can be utilised to manage ongoing pandemic cases and deaths?. Authorea. May 10, 2021.

DOI: 10.22541/au.162066514.40049074/v1

\section{Extra - Tables For Data}

\section{Table - 1- All Health Facilities - ANC services}




\begin{tabular}{|c|c|c|c|c|c|c|c|c|}
\hline $\begin{array}{l}\text { Indicator/ } \\
\text { Variables }\end{array}$ & $\begin{array}{l}\text { Grand } \\
\text { Total Jan- } \\
\text { May } 2021\end{array}$ & $\begin{array}{l}\text { Average } \\
\text { per } \\
\text { Month } \\
\text { up to } \\
\text { May } \\
2021\end{array}$ & $\begin{array}{l}\text { Grand } \\
\text { Total Jan- } \\
\text { Dec } 2020\end{array}$ & $\begin{array}{l}\text { Average } \\
\text { per Month } \\
2020\end{array}$ & $\begin{array}{l}\text { Grand } \\
\text { Total Jan- } \\
\text { Dec } 2019\end{array}$ & $\begin{array}{l}\text { Average } \\
\text { per } \\
\text { Month } \\
2019\end{array}$ & $\begin{array}{l}\text { Grand } \\
\text { Total Jan- } \\
\text { Dec } 2018\end{array}$ & $\begin{array}{l}\text { Average } \\
\text { per } \\
\text { Month } \\
2018\end{array}$ \\
\hline $\begin{array}{l}\text { Total number } \\
\text { of pregnant } \\
\text { women } \\
\text { registered for } \\
\text { ANC }\end{array}$ & 11705003 & 2341001 & 27331061 & 2277588.4 & 29239176 & 2436598 & 28715284 & 2392940 \\
\hline $\begin{array}{l}\text { Out of the total } \\
\text { ANC } \\
\text { registered, } \\
\text { number } \\
\text { registered } \\
\text { within } 1 \text { st } \\
\text { trimester } \\
\text { (within } 12 \\
\text { weeks) }\end{array}$ & 8857190 & 1771438 & 20159599 & 1679966.6 & 20651001 & 1720917 & 19241988 & 1603499 \\
\hline $\begin{array}{l}\text { Number of PW } \\
\text { given TT1/ } \\
\text { Td1 }\end{array}$ & 8373701 & 1674740 & 19519707 & 1626642.3 & 20914454 & 1742871 & 20721613 & 1726801 \\
\hline $\begin{array}{l}\text { Number of PW } \\
\text { given TT2 / } \\
\text { Td2 }\end{array}$ & 7315183 & 1463037 & 17474638 & 1456219.8 & 18690487 & 1557541 & 18649203 & 1554100 \\
\hline $\begin{array}{l}\text { Number of PW } \\
\text { given TT } \\
\text { Booster/ Td } \\
\text { Booster }\end{array}$ & 2586422 & 517284.4 & 6151009 & 512584.08 & 6126384 & 510532 & 5805114 & 483759.5 \\
\hline $\begin{array}{l}\text { Number of PW } \\
\text { provided full } \\
\text { Course } 180 \\
\text { Iron Folic Acid } \\
\text { (IFA) tablets }\end{array}$ & 10498110 & 2099622 & 24745654 & 2062137.8 & 25914433 & 2159536 & 23827573 & 1985631 \\
\hline $\begin{array}{l}\text { Number of PW } \\
\text { provided full } \\
\text { Course } 360 \\
\text { Calcium } \\
\text { tablets }\end{array}$ & 9536074 & 1907215 & 21590545 & 1799212.1 & 20071256 & 1672605 & 15308904 & 1275742 \\
\hline $\begin{array}{l}\text { Number of PW } \\
\text { given one } \\
\text { Albendazole } \\
\text { tablet after 1st } \\
\text { trimester }\end{array}$ & 5914302 & 1182860 & 13256472 & 1104706 & 12398974 & 1033248 & 10299836 & 858319.7 \\
\hline $\begin{array}{l}\text { Number of PW } \\
\text { received } 4 \text { or } \\
\text { more ANC } \\
\text { check ups }\end{array}$ & 9050827 & 1810165 & 21503916 & 1791993 & 22797902 & 1899825 & 20454580 & 1704548 \\
\hline $\begin{array}{l}\text { Number of PW } \\
\text { given ANC } \\
\text { Corticosteroids } \\
\text { in Pre Term } \\
\text { Labour }\end{array}$ & 193519 & 38703.8 & 448066 & 37338.833 & 438607 & 36550.58 & 422207 & 35183.92 \\
\hline $\begin{array}{l}\text { New cases of } \\
\text { PW with } \\
\text { hypertension } \\
\text { detected }\end{array}$ & 235295 & 47059 & 561945 & 46828.75 & 596384 & 49698.67 & 570441 & 47536.75 \\
\hline Out of the new & 167139 & 33427.8 & 404487 & 33707.25 & 409638 & 34136.5 & 369953 & 30829.42 \\
\hline
\end{tabular}


cases of PW

with

hypertension

detected,

cases

managed at

institution

Number of

23372

$4674.4 \quad 65146$

$5428.8333 \quad 66706$

$5558.833 \quad 53435$

4452.917

Eclampsia

cases

managed

during delivery

$\begin{array}{lllllllll}\text { Number of PW } & 9086072 & 1817214 & 21486690 & 1790557.5 & 24089887 & 2007491 & 22164234 & 1847020\end{array}$

tested for

Haemoglobin

$(\mathrm{Hb}) 4$ or more

than 4 times

for respective

ANCs

$\begin{array}{lllllllll}\text { Number of PW } & 7557869 & 1511574 & 18056856 & 1504738 & 20886670 & 1740556 & 20066753 & 1672229\end{array}$

having $\mathrm{Hb}$

level< 11 (out

of total tested

cases)(7.1 to

10.9)

having $\mathrm{Hb}$

level<7 (out of

total tested

cases)

Number of PW

having severe

214203

$42840.6 \quad 544519$

$45376.583 \quad 645662$

$53805.17 \quad 537769$

44814.08

anaemia $(\mathrm{Hb}<$

7) treated

\begin{tabular}{|c|c|c|c|c|c|c|c|c|}
\hline $\begin{array}{l}\text { Number of PW } \\
\text { tested for } \\
\text { Blood Sugar }\end{array}$ & 1950046 & 390009.2 & 4154191 & 346182.58 & 4554319 & 379526.6 & 3699947 & 308328.9 \\
\hline
\end{tabular}

using

OGTT(Oral

Glucose

Tolerance

Test)

Number of PW

59466

$11893.2 \quad 116438$

$9703.1667 \quad 145591$

$12132.58 \quad 130073$

10839.42

for GDM

Number of PW

given insulin

out of total

tested positive

for GDM

$\begin{array}{lllllllll}\text { Number of PW } & 1273526 & 254705.2 & 2106957 & 175579.75 & 639764 & 53313.67 & 136377 & 11364.75\end{array}$

tested using

POC test for

Syphilis

\begin{tabular}{lllllllll}
$\begin{array}{l}\text { Out of above, } \\
\text { number of PW } \\
\text { found sero- } \\
\text { positive for }\end{array}$ & 10722 & 2144.4 & 10267 & 855.58333 & 5032 & 419.3333 & 4069 & 339.0833 \\
\begin{tabular}{l} 
Syphilis \\
\hline Number of
\end{tabular} & 3522324 & 704464.8 & 8221419 & 685118.25 & 9965701 & 830475.1 & 7617933 & 634827.8 \\
\hline
\end{tabular}




\begin{tabular}{|c|c|c|c|c|c|c|c|c|}
\hline $\begin{array}{l}\text { Number of } \\
\text { pregnant } \\
\text { women tested } \\
\text { found sero } \\
\text { positive for } \\
\text { Syphilis }\end{array}$ & 19916 & 3983.2 & 40303 & 3358.5833 & 43058 & 3588.167 & 45107 & 3758.917 \\
\hline $\begin{array}{l}\text { Number of } \\
\text { syphilis } \\
\text { positive } \\
\text { pregnant } \\
\text { women treated } \\
\text { for Syphilis }\end{array}$ & 10098 & 2019.6 & 13530 & 1127.5 & 14911 & 1242.583 & 15362 & 1280.167 \\
\hline
\end{tabular}

Table - 2-Public Health Facilities - ANC services 


\begin{tabular}{|c|c|c|c|c|c|c|c|c|}
\hline $\begin{array}{l}\text { Indicator / } \\
\text { Variables }\end{array}$ & $\begin{array}{l}\text { Total } \\
\text { Public } \\
2021 \text { Jan- } \\
\text { May } \\
2021\end{array}$ & $\begin{array}{l}\text { Public } \\
\text { Average } \\
\text { per } \\
\text { Month up } \\
\text { to May } \\
2021\end{array}$ & $\begin{array}{l}\text { Total } \\
\text { Public } \\
2021 \text { Jan- } \\
\text { Dec } 2020\end{array}$ & $\begin{array}{l}\text { Public } \\
\text { Average } \\
\text { per } \\
\text { Month } \\
\text { Jan to } \\
\text { Dec } 2020\end{array}$ & $\begin{array}{l}\text { Total } \\
\text { Public } \\
\text { 2021 Jan- } \\
\text { Dec } 2019\end{array}$ & $\begin{array}{l}\text { Average } \\
\text { Public } \\
\text { per } \\
\text { Month } \\
\text { Jan to } \\
\text { Dec } 2019\end{array}$ & $\begin{array}{l}\text { Total } \\
\text { Public } \\
\text { 2021 Jan- } \\
\text { Dec } 2018\end{array}$ & $\begin{array}{l}\text { Average } \\
\text { Public } \\
\text { per } \\
\text { Month } \\
\text { Jan to } \\
\text { Dec 2018 }\end{array}$ \\
\hline $\begin{array}{l}\text { Total number of } \\
\text { pregnant } \\
\text { women } \\
\text { registered for } \\
\text { ANC }\end{array}$ & 11160472 & 2232094 & 26211748 & 2184312 & 27957956 & 2329830 & 27586683 & 2298890 \\
\hline $\begin{array}{l}\text { Out of the total } \\
\text { ANC registered, } \\
\text { number } \\
\text { registered } \\
\text { within } 1 \text { st } \\
\text { trimester (within } \\
12 \text { weeks) }\end{array}$ & 8514618 & 1702924 & 19461371 & 1621781 & 19929073 & 1660756 & 18601648 & 1550137 \\
\hline $\begin{array}{l}\text { Number of PW } \\
\text { given TT1/ Td1 }\end{array}$ & 7928918 & 1585784 & 18556764 & 1546397 & 19831929 & 1652661 & 19663083 & 1638590 \\
\hline $\begin{array}{l}\text { Number of PW } \\
\text { given TT2 / Td2 }\end{array}$ & 6973390 & 1394678 & 16686440 & 1390537 & 17788326 & 1482361 & 17755840 & 1479653 \\
\hline $\begin{array}{l}\text { Number of PW } \\
\text { given TT } \\
\text { Booster/ Td } \\
\text { Booster }\end{array}$ & 2459103 & 491820.6 & 5892987 & 491082.3 & 5848872 & 487406 & 5577398 & 464783.2 \\
\hline $\begin{array}{l}\text { Number of PW } \\
\text { provided full } \\
\text { Course } 180 \text { Iron } \\
\text { Folic Acid (IFA) } \\
\text { tablets }\end{array}$ & 10076105 & 2015221 & 23877961 & 1989830 & 25142496 & 2095208 & 23090927 & 1924244 \\
\hline $\begin{array}{l}\text { Number of PW } \\
\text { provided full } \\
\text { Course } 360 \\
\text { Calcium tablets }\end{array}$ & 9152196 & 1830439 & 20806254 & 1733855 & 19406749 & 1617229 & 14675806 & 1222984 \\
\hline $\begin{array}{l}\text { Number of PW } \\
\text { given one } \\
\text { Albendazole } \\
\text { tablet after 1st } \\
\text { trimester }\end{array}$ & 5733438 & 1146688 & 12929270 & 1077439 & 12165461 & 1013788 & 10105919 & 842159.9 \\
\hline $\begin{array}{l}\text { Number of PW } \\
\text { received } 4 \text { or } \\
\text { more ANC } \\
\text { check ups }\end{array}$ & 8665872 & 1733174 & 20723099 & 1726925 & 22004864 & 1833739 & 19749980 & 1645832 \\
\hline $\begin{array}{l}\text { Number of PW } \\
\text { given ANC } \\
\text { Corticosteroids } \\
\text { in Pre Term } \\
\text { Labour }\end{array}$ & 176745 & 35349 & 414603 & 34550.25 & 395614 & 32967.83 & 384783 & 32065.25 \\
\hline $\begin{array}{l}\text { New cases of } \\
\text { PW with } \\
\text { hypertension } \\
\text { detected }\end{array}$ & 210113 & 42022.6 & 514198 & 42849.83 & 540639 & 45053.25 & 515305 & 42942.08 \\
\hline $\begin{array}{l}\text { Out of the new } \\
\text { cases of PW } \\
\text { with } \\
\text { hypertension } \\
\text { detected, cases }\end{array}$ & 148783 & 29756.6 & 370422 & 30868.5 & 372165 & 31013.75 & 335727 & 27977.25 \\
\hline
\end{tabular}




\begin{tabular}{|c|c|c|c|c|c|c|c|c|}
\hline $\begin{array}{l}\text { Number of } \\
\text { Eclampsia } \\
\text { cases managed } \\
\text { during delivery }\end{array}$ & 21481 & 4296.2 & 59543 & 4961.917 & 60550 & 5045.833 & 49994 & 4166.167 \\
\hline $\begin{array}{l}\text { Number of PW } \\
\text { tested for } \\
\text { Haemoglobin } \\
(\mathrm{Hb}) 4 \text { or more } \\
\text { than } 4 \text { times for } \\
\text { respective ANCs }\end{array}$ & 8730348 & 1746070 & 20775686 & 1731307 & 23393149 & 1949429 & 21588252 & 1799021 \\
\hline $\begin{array}{l}\text { Number of PW } \\
\text { having Hb } \\
\text { level<11 (out of } \\
\text { total tested } \\
\text { cases)(7.1 to } \\
10.9)\end{array}$ & 7362887 & 1472577 & 17605494 & 1467125 & 20399373 & 1699948 & 19620171 & 1635014 \\
\hline $\begin{array}{l}\text { Number of PW } \\
\text { having Hb } \\
\text { level<7 (out of } \\
\text { total tested } \\
\text { cases) }\end{array}$ & 332124 & 66424.8 & 846582 & 70548.5 & 1034914 & 86242.83 & 978090 & 81507.5 \\
\hline $\begin{array}{l}\text { Number of PW } \\
\text { having severe } \\
\text { anaemia (Hb < } \\
\text { 7) treated }\end{array}$ & 197901 & 39580.2 & 506875 & 42239.58 & 602132 & 50177.67 & 501991 & 41832.58 \\
\hline $\begin{array}{l}\text { Number of PW } \\
\text { tested for Blood } \\
\text { Sugar using } \\
\text { OGTT(Oral } \\
\text { Glucose } \\
\text { Tolerance Test) }\end{array}$ & 1771947 & 354389.4 & 3821991 & 318499.3 & 4259770 & 354980.8 & 3435677 & 286306.4 \\
\hline $\begin{array}{l}\text { Number of PW } \\
\text { tested positive } \\
\text { for GDM }\end{array}$ & 46516 & 9303.2 & 94170 & 7847.5 & 124008 & 10334 & 109062 & 9088.5 \\
\hline $\begin{array}{l}\text { Number of PW } \\
\text { given insulin } \\
\text { out of total } \\
\text { tested positive } \\
\text { for GDM }\end{array}$ & 12474 & 2494.8 & 22963 & 1913.583 & 21787 & 1815.583 & 17926 & 1493.833 \\
\hline $\begin{array}{l}\text { Number of PW } \\
\text { tested using } \\
\text { POC test for } \\
\text { Syphilis }\end{array}$ & 1273485 & 254697 & 2106573 & 175547.8 & 639535 & 53294.58 & 136118 & 11343.17 \\
\hline $\begin{array}{l}\text { Out of above, } \\
\text { number of PW } \\
\text { found sero } \\
\text { positive for } \\
\text { Syphilis }\end{array}$ & 10722 & 2144.4 & 10267 & 855.5833 & 5032 & 419.3333 & 4069 & 339.0833 \\
\hline $\begin{array}{l}\text { Number of } \\
\text { pregnant } \\
\text { women tested } \\
\text { for Syphilis }\end{array}$ & 3263317 & 652663.4 & 7736855 & 644737.9 & 9527811 & 793984.3 & 7327164 & 610597 \\
\hline $\begin{array}{l}\text { Number of } \\
\text { pregnant } \\
\text { women tested } \\
\text { found sero }\end{array}$ & 18695 & 3739 & 38195 & 3182.917 & 41357 & 3446.417 & 43500 & 3625 \\
\hline
\end{tabular}


positive for

Syphilis

Number of

9252

$1850.4 \quad 12268$

1022.333

14296

1191.333

14917

1243.083

syphilis positive

pregnant

women treated

for Syphilis

Table - 3 - Private Health Facilities - ANC services 


\begin{tabular}{|c|c|c|c|c|c|c|c|c|}
\hline Indicator / Variables & $\begin{array}{l}\text { Total } \\
\text { Private } \\
2021 \\
\text { Jan- } \\
\text { May } \\
2021\end{array}$ & $\begin{array}{l}\text { Private } \\
\text { Average } \\
\text { per } \\
\text { Month up } \\
\text { to May } \\
2021\end{array}$ & $\begin{array}{l}\text { Total } \\
\text { Private } \\
2021 \\
\text { Jan-Dec } \\
2020\end{array}$ & $\begin{array}{l}\text { Private } \\
\text { Average } \\
\text { per } \\
\text { Month } \\
\text { Jan to } \\
\text { Dec } 2020\end{array}$ & $\begin{array}{l}\text { Total } \\
\text { Private } \\
2021 \\
\text { Jan-Dec } \\
2019\end{array}$ & $\begin{array}{l}\text { Private } \\
\text { Average } \\
\text { per } \\
\text { Month } \\
\text { Jan to } \\
\text { Dec } 2019\end{array}$ & $\begin{array}{l}\text { Total } \\
\text { Private } \\
2021 \\
\text { Jan-Dec } \\
2018\end{array}$ & $\begin{array}{l}\text { Private } \\
\text { Average } \\
\text { per } \\
\text { Month } \\
\text { Jan to } \\
\text { Dec 2018 }\end{array}$ \\
\hline $\begin{array}{l}\text { Total number of } \\
\text { pregnant women } \\
\text { registered for ANC }\end{array}$ & 544531 & 108906.2 & 1119313 & 93276.08 & 1281220 & 106768.3 & 1128601 & 94050.08 \\
\hline $\begin{array}{l}\text { Out of the total ANC } \\
\text { registered, number } \\
\text { registered within } 1 \text { st } \\
\text { trimester (within } 12 \\
\text { weeks) }\end{array}$ & 342572 & 68514.4 & 698228 & 58185.67 & 721928 & 60160.67 & 640340 & 53361.67 \\
\hline $\begin{array}{l}\text { Number of PW given } \\
\text { TT1/ Td1 }\end{array}$ & 444783 & 88956.6 & 962943 & 80245.25 & 1082525 & 90210.42 & 1058530 & 88210.83 \\
\hline $\begin{array}{l}\text { Number of PW given } \\
\text { TT2 / Td2 }\end{array}$ & 341793 & 68358.6 & 788198 & 65683.17 & 902161 & 75180.08 & 893363 & 74446.92 \\
\hline $\begin{array}{l}\text { Number of PW given } \\
\text { TT Booster/ Td } \\
\text { Booster }\end{array}$ & 127319 & 25463.8 & 258022 & 21501.83 & 277512 & 23126 & 227716 & 18976.33 \\
\hline $\begin{array}{l}\text { Number of PW } \\
\text { provided full Course } \\
180 \text { Iron Folic Acid } \\
\text { (IFA) tablets }\end{array}$ & 422005 & 84401 & 867693 & 72307.75 & 771937 & 64328.08 & 736646 & 61387.17 \\
\hline $\begin{array}{l}\text { Number of PW } \\
\text { provided full Course } \\
360 \text { Calcium tablets }\end{array}$ & 383878 & 76775.6 & 784291 & 65357.58 & 664507 & 55375.58 & 633098 & 52758.17 \\
\hline $\begin{array}{l}\text { Number of PW given } \\
\text { one Albendazole } \\
\text { tablet after } 1 \text { st } \\
\text { trimester }\end{array}$ & 180864 & 36172.8 & 327202 & 27266.83 & 233513 & 19459.42 & 193917 & 16159.75 \\
\hline $\begin{array}{l}\text { Number of PW } \\
\text { received } 4 \text { or more } \\
\text { ANC check ups }\end{array}$ & 384955 & 76991 & 780817 & 65068.08 & 793038 & 66086.5 & 704600 & 58716.67 \\
\hline $\begin{array}{l}\text { Number of PW given } \\
\text { ANC Corticosteroids } \\
\text { in Pre Term Labour }\end{array}$ & 16774 & 3354.8 & 33463 & 2788.583 & 42993 & 3582.75 & 37424 & 3118.667 \\
\hline $\begin{array}{l}\text { New cases of PW } \\
\text { with hypertension } \\
\text { detected }\end{array}$ & 25182 & 5036.4 & 47747 & 3978.917 & 55745 & 4645.417 & 55136 & 4594.667 \\
\hline $\begin{array}{l}\text { Out of the new cases } \\
\text { of PW with } \\
\text { hypertension } \\
\text { detected, cases } \\
\text { managed at } \\
\text { institution }\end{array}$ & 18356 & 3671.2 & 34065 & 2838.75 & 37473 & 3122.75 & 34226 & 2852.167 \\
\hline $\begin{array}{l}\text { Number of } \\
\text { Eclampsia cases } \\
\text { managed during } \\
\text { delivery }\end{array}$ & 1891 & 378.2 & 5603 & 466.9167 & 6156 & 513 & 3441 & 286.75 \\
\hline $\begin{array}{l}\text { Number of PW tested } \\
\text { for Haemoglobin (Hb } \\
\text { ) } 4 \text { or more than } 4 \\
\text { times for respective } \\
\text { ANCs }\end{array}$ & 355724 & 71144.8 & 711004 & 59250.33 & 696738 & 58061.5 & 575982 & 47998.5 \\
\hline
\end{tabular}




\begin{tabular}{|c|c|c|c|c|c|c|c|c|}
\hline $\begin{array}{l}\text { Number of PW } \\
\text { having Hb level<11 } \\
\text { (out of total tested } \\
\text { cases)(7.1 to 10.9) }\end{array}$ & 194982 & 38996.4 & 451362 & 37613.5 & 487297 & 40608.08 & 446582 & 37215.17 \\
\hline $\begin{array}{l}\text { Number of PW } \\
\text { having } \mathrm{Hb} \text { level<7 } \\
\text { (out of total tested } \\
\text { cases) }\end{array}$ & 21752 & 4350.4 & 48348 & 4029 & 57944 & 4828.667 & 58779 & 4898.25 \\
\hline $\begin{array}{l}\text { Number of PW } \\
\text { having severe } \\
\text { anaemia }(\mathrm{Hb}<7) \\
\text { treated }\end{array}$ & 16302 & 3260.4 & 37644 & 3137 & 43530 & 3627.5 & 35778 & 2981.5 \\
\hline $\begin{array}{l}\text { Number of PW tested } \\
\text { for Blood Sugar } \\
\text { using OGTT(Oral } \\
\text { Glucose Tolerance } \\
\text { Test) }\end{array}$ & 178099 & 35619.8 & 332200 & 27683.33 & 294549 & 24545.75 & 264270 & 22022.5 \\
\hline $\begin{array}{l}\text { Number of PW tested } \\
\text { positive for GDM }\end{array}$ & 12950 & 2590 & 22268 & 1855.667 & 21583 & 1798.583 & 21011 & 1750.917 \\
\hline $\begin{array}{l}\text { Number of PW given } \\
\text { insulin out of total } \\
\text { tested positive for } \\
\text { GDM }\end{array}$ & 4597 & 919.4 & 7836 & 653 & 8247 & 687.25 & 7922 & 660.1667 \\
\hline $\begin{array}{l}\text { Number of PW tested } \\
\text { using POC test for } \\
\text { Syphilis }\end{array}$ & 41 & 8.2 & 384 & 32 & 229 & 19.08333 & 259 & 21.58333 \\
\hline $\begin{array}{l}\text { Out of above, number } \\
\text { of PW found sero } \\
\text { positive for Syphilis }\end{array}$ & 0 & 0 & 0 & 0 & 0 & 0 & 0 & 0 \\
\hline $\begin{array}{l}\text { Number of pregnant } \\
\text { women tested for } \\
\text { Syphilis }\end{array}$ & 259007 & 51801.4 & 484564 & 40380.33 & 437890 & 36490.83 & 290769 & 24230.75 \\
\hline $\begin{array}{l}\text { Number of pregnant } \\
\text { women tested found } \\
\text { sero positive for } \\
\text { Syphilis }\end{array}$ & 1221 & 244.2 & 2108 & 175.6667 & 1701 & 141.75 & 1607 & 133.9167 \\
\hline $\begin{array}{l}\text { Number of syphilis } \\
\text { positive pregnant } \\
\text { women treated for } \\
\text { Syphilis }\end{array}$ & 846 & 169.2 & 1262 & 105.1667 & 615 & 51.25 & 445 & 37.08333 \\
\hline
\end{tabular}

Table - 4- Urban Health Facilities - ANC services 


\begin{tabular}{|c|c|c|c|c|c|c|c|c|}
\hline Indicator / Variables & $\begin{array}{l}\text { Total } \\
\text { Urban } \\
2021 \\
\text { Jan-May } \\
2021\end{array}$ & $\begin{array}{l}\text { Urban } \\
\text { Average } \\
\text { per } \\
\text { Month up } \\
\text { to May } \\
2021\end{array}$ & $\begin{array}{l}\text { Total } \\
\text { Urban } \\
2021 \\
\text { Jan-Dec } \\
2020\end{array}$ & $\begin{array}{l}\text { Urban } \\
\text { Average } \\
\text { per } \\
\text { Month } \\
\text { Jan to } \\
\text { Dec } 2020\end{array}$ & $\begin{array}{l}\text { Total } \\
\text { Urban } \\
2021 \\
\text { Jan-Dec } \\
2019\end{array}$ & $\begin{array}{l}\text { Urban } \\
\text { Average } \\
\text { per } \\
\text { Month } \\
\text { Jan to } \\
\text { Dec } 2019\end{array}$ & $\begin{array}{l}\text { Total } \\
\text { Urban } \\
2021 \\
\text { Jan-Dec } \\
2018\end{array}$ & $\begin{array}{l}\text { Urban } \\
\text { Average } \\
\text { per } \\
\text { Month } \\
\text { Jan to } \\
\text { Dec 2018 }\end{array}$ \\
\hline $\begin{array}{l}\text { Total number of } \\
\text { pregnant women } \\
\text { registered for ANC }\end{array}$ & 2799199 & 559839.8 & 5732434 & 477702.8 & 5522753 & 460229.4 & 5315496 & 442958 \\
\hline $\begin{array}{l}\text { Out of the total ANC } \\
\text { registered, number } \\
\text { registered within } 1 \text { st } \\
\text { trimester (within } 12 \\
\text { weeks) }\end{array}$ & 1861673 & 372334.6 & 3773658 & 314471.5 & 3516878 & 293073.2 & 3191862 & 265988.5 \\
\hline $\begin{array}{l}\text { Number of PW given } \\
\text { TT1/ Td1 }\end{array}$ & 1874643 & 374928.6 & 3889902 & 324158.5 & 3781616 & 315134.7 & 3675646 & 306303.8 \\
\hline $\begin{array}{l}\text { Number of PW given } \\
\text { TT2 / Td2 }\end{array}$ & 1559647 & 311929.4 & 3305543 & 275461.9 & 3270384 & 272532 & 3204310 & 267025.8 \\
\hline $\begin{array}{l}\text { Number of PW given } \\
\text { TT Booster/ Td } \\
\text { Booster }\end{array}$ & 548880 & 109776 & 1152598 & 96049.83 & 1072381 & 89365.08 & 976894 & 81407.83 \\
\hline $\begin{array}{l}\text { Number of PW } \\
\text { provided full Course } \\
180 \text { Iron Folic Acid } \\
\text { (IFA) tablets }\end{array}$ & 2595186 & 519037.2 & 5370533 & 447544.4 & 5025207 & 418767.3 & 4414141 & 367845.1 \\
\hline $\begin{array}{l}\text { Number of PW } \\
\text { provided full Course } \\
360 \text { Calcium tablets }\end{array}$ & 2480328 & 496065.6 & 4885364 & 407113.7 & 4159912 & 346659.3 & 3350943 & 279245.3 \\
\hline $\begin{array}{l}\text { Number of PW given } \\
\text { one Albendazole } \\
\text { tablet after 1st } \\
\text { trimester }\end{array}$ & 1246800 & 249360 & 2469203 & 205766.9 & 2059035 & 171586.3 & 1665584 & 138798.7 \\
\hline $\begin{array}{l}\text { Number of PW } \\
\text { received } 4 \text { or more } \\
\text { ANC check ups }\end{array}$ & 1982283 & 396456.6 & 4155099 & 346258.3 & 3695493 & 307957.8 & 3436649 & 286387.4 \\
\hline $\begin{array}{l}\text { Number of PW given } \\
\text { ANC Corticosteroids } \\
\text { in Pre Term Labour }\end{array}$ & 85226 & 17045.2 & 167332 & 13944.33 & 94715 & 7892.917 & 85234 & 7102.833 \\
\hline $\begin{array}{l}\text { New cases of PW } \\
\text { with hypertension } \\
\text { detected }\end{array}$ & 95254 & 19050.8 & 181014 & 15084.5 & 122078 & 10173.17 & 121289 & 10107.42 \\
\hline $\begin{array}{l}\text { Out of the new } \\
\text { cases of PW with } \\
\text { hypertension } \\
\text { detected, cases } \\
\text { managed at } \\
\text { institution }\end{array}$ & 73207 & 14641.4 & 135166 & 11263.83 & 89324 & 7443.667 & 82262 & 6855.167 \\
\hline $\begin{array}{l}\text { Number of } \\
\text { Eclampsia cases } \\
\text { managed during } \\
\text { delivery }\end{array}$ & 12264 & 2452.8 & 29353 & 2446.083 & 12377 & 1031.417 & 9233 & 769.4167 \\
\hline $\begin{array}{l}\text { Number of PW } \\
\text { tested for } \\
\text { Haemoglobin }(\mathrm{Hb}) \\
4 \text { or more than } 4 \\
\text { times for respective } \\
\text { ANCs }\end{array}$ & 1807395 & 361479 & 3809940 & 317495 & 3675673 & 306306.1 & 3318523 & 276543.6 \\
\hline
\end{tabular}




\begin{tabular}{|c|c|c|c|c|c|c|c|c|}
\hline $\begin{array}{l}\text { Number of PW } \\
\text { having Hb level<11 } \\
\text { (out of total tested } \\
\text { cases)(7.1 to 10.9) }\end{array}$ & 1663484 & 332696.8 & 3507576 & 292298 & 3569087 & 297423.9 & 3593977 & 299498.1 \\
\hline $\begin{array}{l}\text { Number of PW } \\
\text { having } \mathrm{Hb} \text { level<7 } \\
\text { (out of total tested } \\
\text { cases) }\end{array}$ & 122577 & 24515.4 & 233239 & 19436.58 & 180239 & 15019.92 & 203247 & 16937.25 \\
\hline $\begin{array}{l}\text { Number of PW } \\
\text { having severe } \\
\text { anaemia }(\mathrm{Hb}<7) \\
\text { treated }\end{array}$ & 94726 & 18945.2 & 178698 & 14891.5 & 114580 & 9548.333 & 111620 & 9301.667 \\
\hline $\begin{array}{l}\text { Number of PW } \\
\text { tested for Blood } \\
\text { Sugar using } \\
\text { OGTT(Oral Glucose } \\
\text { Tolerance Test) }\end{array}$ & 714372 & 142874.4 & 1289771 & 107480.9 & 958592 & 79882.67 & 828488 & 69040.67 \\
\hline $\begin{array}{l}\text { Number of PW } \\
\text { tested positive for } \\
\text { GDM }\end{array}$ & 30337 & 6067.4 & 48041 & 4003.417 & 31688 & 2640.667 & 34854 & 2904.5 \\
\hline $\begin{array}{l}\text { Number of PW given } \\
\text { insulin out of total } \\
\text { tested positive for } \\
\text { GDM }\end{array}$ & 10755 & 2151 & 13484 & 1123.667 & 8956 & 746.3333 & 8310 & 692.5 \\
\hline $\begin{array}{l}\text { Number of PW } \\
\text { tested using POC } \\
\text { test for Syphilis }\end{array}$ & 3924 & 784.8 & 8202 & 683.5 & 4858 & 404.8333 & 3017 & 251.4167 \\
\hline $\begin{array}{l}\text { Out of above, } \\
\text { number of PW } \\
\text { found sero positive } \\
\text { for Syphilis }\end{array}$ & 145 & 29 & 260 & 21.66667 & 95 & 7.916667 & 209 & 17.41667 \\
\hline $\begin{array}{l}\text { Number of pregnant } \\
\text { women tested for } \\
\text { Syphilis }\end{array}$ & 1398620 & 279724 & 2781314 & 231776.2 & 2089149 & 174095.8 & 1591245 & 132603.8 \\
\hline $\begin{array}{l}\text { Number of pregnant } \\
\text { women tested found } \\
\text { sero positive for } \\
\text { Syphilis }\end{array}$ & 8205 & 1641 & 11576 & 964.6667 & 9635 & 802.9167 & 15494 & 1291.167 \\
\hline $\begin{array}{l}\text { Number of syphilis } \\
\text { positive pregnant } \\
\text { women treated for } \\
\text { Syphilis }\end{array}$ & 3476 & 695.2 & 3825 & 318.75 & 3257 & 271.4167 & 2615 & 217.9167 \\
\hline
\end{tabular}

Table - 5 - Rural Health Facilities - ANC services 


\begin{tabular}{|c|c|c|c|c|c|c|c|c|}
\hline Indicator & $\begin{array}{l}\text { Total } \\
\text { Rural } \\
2021 \\
\text { Jan-May } \\
2021\end{array}$ & $\begin{array}{l}\text { Rural } \\
\text { Average } \\
\text { per } \\
\text { Month up } \\
\text { to May } \\
2021\end{array}$ & $\begin{array}{l}\text { Total } \\
\text { Rural } \\
2021 \text { Jan- } \\
\text { Dec } 2020\end{array}$ & $\begin{array}{l}\text { Rural } \\
\text { Average } \\
\text { per } \\
\text { Month } \\
\text { Jan to } \\
\text { Dec } 2020\end{array}$ & $\begin{array}{l}\text { Total } \\
\text { Rural } \\
2021 \text { Jan- } \\
\text { Dec } 2019\end{array}$ & $\begin{array}{l}\text { Rural } \\
\text { Average } \\
\text { per } \\
\text { Month } \\
\text { Jan to } \\
\text { Dec } 2019\end{array}$ & $\begin{array}{l}\text { Total } \\
\text { Rural } \\
2021 \text { Jan- } \\
\text { Dec } 2018\end{array}$ & $\begin{array}{l}\text { Rural } \\
\text { Average } \\
\text { per } \\
\text { Month } \\
\text { Jan to } \\
\text { Dec 2018 }\end{array}$ \\
\hline $\begin{array}{l}\text { Total number of } \\
\text { pregnant women } \\
\text { registered for } \\
\text { ANC }\end{array}$ & 8905795 & 1781159 & 21598577 & 1799881 & 23716423 & 1976369 & 23399788 & 1949982 \\
\hline $\begin{array}{l}\text { Out of the total } \\
\text { ANC registered, } \\
\text { number } \\
\text { registered within } \\
\text { 1st trimester } \\
\text { (within } 12 \\
\text { weeks) }\end{array}$ & 6995507 & 1399101 & 16385892 & 1365491 & 17134123 & 1427844 & 16050126 & 1337511 \\
\hline $\begin{array}{l}\text { Number of PW } \\
\text { given TT1/ Td1 }\end{array}$ & 6499047 & 1299809 & 15629757 & 1302480 & 17132838 & 1427737 & 17045967 & 1420497 \\
\hline $\begin{array}{l}\text { Number of PW } \\
\text { given TT2 / Td2 }\end{array}$ & 5755512 & 1151102 & 14169045 & 1180754 & 15420103 & 1285009 & 15444893 & 1287074 \\
\hline $\begin{array}{l}\text { Number of PW } \\
\text { given TT } \\
\text { Booster/ Td } \\
\text { Booster }\end{array}$ & 2037542 & 407508.4 & 4998410 & 416534.2 & 5054003 & 421166.9 & 4828220 & 402351.7 \\
\hline $\begin{array}{l}\text { Number of PW } \\
\text { provided full } \\
\text { Course } 180 \text { Iron } \\
\text { Folic Acid (IFA) } \\
\text { tablets }\end{array}$ & 7902913 & 1580583 & 19375067 & 1614589 & 20889226 & 1740769 & 19413432 & 1617786 \\
\hline $\begin{array}{l}\text { Number of PW } \\
\text { provided full } \\
\text { Course } 360 \\
\text { Calcium tablets }\end{array}$ & 7055735 & 1411147 & 16705127 & 1392094 & 15911344 & 1325945 & 11957961 & 996496.8 \\
\hline $\begin{array}{l}\text { Number of PW } \\
\text { given one } \\
\text { Albendazole } \\
\text { tablet after } 1 \text { st } \\
\text { trimester }\end{array}$ & 4667496 & 933499.2 & 10787238 & 898936.5 & 10339939 & 861661.6 & 8634252 & 719521 \\
\hline $\begin{array}{l}\text { Number of PW } \\
\text { received } 4 \text { or } \\
\text { more ANC check } \\
\text { ups }\end{array}$ & 7068527 & 1413705 & 17348781 & 1445732 & 19102409 & 1591867 & 17017931 & 1418161 \\
\hline $\begin{array}{l}\text { Number of PW } \\
\text { given ANC } \\
\text { Corticosteroids in } \\
\text { Pre Term Labour }\end{array}$ & 108293 & 21658.6 & 280734 & 23394.5 & 343892 & 28657.67 & 336973 & 28081.08 \\
\hline $\begin{array}{l}\text { New cases of PW } \\
\text { with } \\
\text { hypertension } \\
\text { detected }\end{array}$ & 140041 & 28008.2 & 380931 & 31744.25 & 474306 & 39525.5 & 449152 & 37429.33 \\
\hline $\begin{array}{l}\text { Out of the new } \\
\text { cases of PW with } \\
\text { hypertension } \\
\text { detected, cases } \\
\text { managed at } \\
\text { institution }\end{array}$ & 93932 & 18786.4 & 269321 & 22443.42 & 320314 & 26692.83 & 287691 & 23974.25 \\
\hline Number of & 11108 & 2221.6 & 35793 & 2982.75 & 54329 & 4527.417 & 44202 & 3683.5 \\
\hline
\end{tabular}




\begin{tabular}{|c|c|c|c|c|c|c|c|c|}
\hline $\begin{array}{l}\text { Number of PW } \\
\text { tested for } \\
\text { Haemoglobin } \\
\text { (Hb) } 4 \text { or more } \\
\text { than } 4 \text { times for } \\
\text { respective ANCs }\end{array}$ & 7278667 & 1455733 & 17676713 & 1473059 & 20414214 & 1701185 & 18845711 & 1570476 \\
\hline $\begin{array}{l}\text { Number of PW } \\
\text { having } \mathrm{Hb} \\
\text { level<11 (out of } \\
\text { total tested } \\
\text { cases)( } 7.1 \text { to } \\
\text { 10.9) }\end{array}$ & 5894375 & 1178875 & 14549176 & 1212431 & 17317583 & 1443132 & 16472776 & 1372731 \\
\hline
\end{tabular}

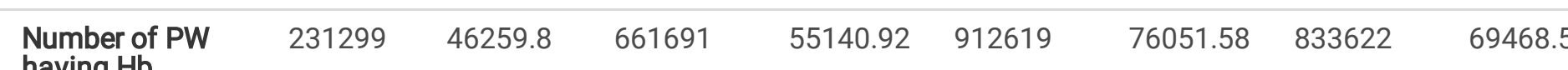

having $\mathrm{Hb}$

level< 7 (out of

total tested

cases)

\begin{tabular}{|c|c|c|c|c|c|c|c|}
\hline $\begin{array}{l}\text { Number of PW } \\
\text { having severe } \\
\text { anaemia }(\mathrm{Hb}<7) \\
\text { treated }\end{array}$ & 119477 & 23895.4 & 365821 & 30485.08 & 531082 & 44256.83 & 35512.42 \\
\hline
\end{tabular}

$\begin{array}{lllllllll}\begin{array}{l}\text { Number of PW } \\ \text { tested for Blood }\end{array} & 1235674 & 247134.8 & 2864405 & 238700.4 & 3595727 & 299643.9 & 2871459 & 239288.3\end{array}$

Sugar using

OGTT(Oral

Glucose

Tolerance Test)

$\begin{array}{lllllllll}\text { Number of PW } & 29129 & 5825.8 & 68397 & 5699.75 & 113903 & 9491.917 & 95219 & 7934.917\end{array}$

tested positive

for GDM

\begin{tabular}{|c|c|c|c|c|c|c|c|c|}
\hline $\begin{array}{l}\text { Number of PW } \\
\text { given insulin out } \\
\text { of total tested } \\
\text { positive for GDM }\end{array}$ & 6316 & 1263.2 & 17315 & 1442.917 & 21078 & 1756.5 & 17538 & 1461.5 \\
\hline $\begin{array}{l}\text { Number of PW } \\
\text { tested using POC } \\
\text { test for Syphilis }\end{array}$ & 1269602 & 253920.4 & 2098755 & 174896.3 & 634906 & 52908.83 & 133360 & 11113.33 \\
\hline $\begin{array}{l}\text { Out of above, } \\
\text { number of PW } \\
\text { found sero } \\
\text { positive for } \\
\text { Syphilis }\end{array}$ & 10577 & 2115.4 & 10007 & 833.9167 & 4937 & 411.4167 & 3860 & 321.6667 \\
\hline $\begin{array}{l}\text { No of pregnant } \\
\text { women tested for } \\
\text { Syphilis }\end{array}$ & 2123704 & 424740.8 & 5440105 & 453342.1 & 7876552 & 656379.3 & 6026688 & 502224 \\
\hline $\begin{array}{l}\text { No of pregnant } \\
\text { women tested } \\
\text { found sero } \\
\text { positive for } \\
\text { Syphilis }\end{array}$ & 11711 & 2342.2 & 28727 & 2393.917 & 33423 & 2785.25 & 29613 & 2467.75 \\
\hline $\begin{array}{l}\text { No of syphilis } \\
\text { positive pregnant } \\
\text { women treated } \\
\text { for Syphilis }\end{array}$ & 6622 & 1324.4 & 9705 & 808.75 & 11654 & 971.1667 & 12747 & 1062.25 \\
\hline
\end{tabular}

